KIDDO : JURNAL PENDIDIKAN ISLAM ANAK USIA DINI
http://kiddo@iainmadura.ac.id
E-ISSN : $2716-1641 ;$ P-ISSN: $2716-0572$

\title{
Penerapan Media Loose Part untuk Kreativitas Anak Usia 5-6 Tahun
}

\author{
Dewi Safitri ${ }^{1}$, Anik Lestariningrum ${ }^{2}$ \\ Universitas Nusantara PGRI Kediri ${ }^{1}$, Indonesia, Universitas Nusantara \\ PGRI Kediri ${ }^{2}$, Indonesia \\ safitrid890@gmail.com, aniklestariningrum@gmail.com
}

\begin{abstract}
This research is motivated by the freedom of children to be creative in expressing the idea of freedom independently without the help of the teacher. This can be seen from the lack of children in completing skills in making free work. Because learning still dominates in guidebooks or LKA. The purpose of the study will describe qualitative research in the application of loose media to the creativity of children aged 5-6 years. The design of this study uses qualitative research with a number of subjects 24 children consisting of 9 girls and 15 boys. Data collection techniques in this study were carried out through observation, documentation, and interview while data analysis techniques used qualitative descriptive analysis of Miles \& Huberman. The results showed that through the media of the loose section can increase children's creativity. From the results of this study, agreed by the teacher, PAUD in increasing children's creativity, can use the loose media media using materials from the environment around children
\end{abstract}

Keywords:

Loose Media Parts;

Creativity;

Early childhood.

\begin{tabular}{lr} 
Abstrak & Kata Kunci: \\
\hline Latar belakang penelitian ini adalah minimnya & Media loose parts; \\
kemampuan anak dalam berkreasi menuangkan ide & Kreativitas; \\
gagasannya secara mandiri tanpa bantuan guru. Hal & Anak usia dini. \\
ini terlihat dari kurangnya anak dalam menyelesaikan & \\
keterampilan dalam membuat suatu karya bebas. & \\
Karena pembelajaran masih terdominasi pada buku & \\
panduan atau LKA. Tujuan penelitian akan & \\
menguraikan secara deskriptif kualitatif & \\
pembelajaran dalam penerapan media loose parts & \\
untuk anak usia 5-6 tahun lebih kreatif. Jumlah \\
subjek penelitian 24 anak,yang terdiri 9 perempuan \\
dan 15 laki-laki dengan menggunakan desain
\end{tabular}


kualitatif. Dan melalui observasi, dokumentasi dan wawancara merupakan Teknik pengumpulan data dalam penelitian ini, dan data dianalisis menggunakan deskriptif kualitatif Miles \& Huberman. Hasil penelitian melalui media loose parts menunjukkan bahwa media tersebut dapat meningkatkan kreativitas anak. Dari hasil penelitian ini disarankan kepada guru PAUD dalam meningkatkan kreativitas anak dapat mengunakan media media loose parts menggunakan bahan dari lingkungan sekitar anak.

Diterima : 27 November; Direvisi: 9 Januari; Diterbitkan: 24 Februari

http://doi.org/10.19105/kiddo.v2i1.3612

\section{Pendahuluan}

Berdasarkan implementasi pembelajaran abad 21 terkait kurikulum 2013 yang telah disosialisasikan oleh Dirjen Dikdasmen Kemendikbud menurut Mulyana, (2017) mencerminkan 4 konsep (1) Critical Thinking and Problem Solving Skill) (2) Communiction (3) Cretivity and Innovation, (4) Collaboration. Untuk membuat manusia lebih kearah kreatif dan produktif serta dapat meningkatkan kualitas hidup dan dapat mempermudah untuk mencari jalan keluar dari sebuah pokok permasalahan yaitu salah satunya dengan meningkatkan kreativitas. Mengapa penekanan kreativitas tentunya keterhambatan pengembangan ini dikarenakan adanya keterbatasan terkait lingkungan main anak dimana rancangan kegiatan bermain bebas banyak aturan yang mengikat.

Konsep terkait akan keterbatasan lingkungan main tentunya juga dipengaruhi semakin sempitnya lahan bermain bebas bagi anak berbeda ketika waktu dulu belum banyak jumlah penduduk. Selain itu lingkungan main sudah banyak tercemar limbah sehingga kurang aman bagi anak. Hal ini juga mempengaruhi terhadap pokok permasalahan terkait kreativitas. Salah satu factor pengembangan kreativitas adalah stimulasi atau rangsangan agar anak tertarik dalam kegiatan mengamati serta mengajukan pertanyaan beragam benda yang dilihat dan kejadian terjadi di lingkungan sekitar. Tentu saja harus dilakukan dengan kegiatan ber,ain sebagai cara belajar anak.

Stimulasi akan pembelajaran kreativitas anak usia dini dapat dilakukan melalui variasi berbagai program bermain anak. Pembelajaran bermain yang dibungkus secara sederhana dan menyenangkan namun dapat memberikan makna untuk kehidupannya kelak. Seperti penelitian yang dilakukan oleh (Istianti, 2018)memperkarya pengembangan kreativitas dengan mengenalkan lingkungan sekitar sebagai sumber belajar 
bermakna bagi anak. Lingkungan akan mengakomodir stimulasi berkaitan dengan dunia nyata dimana sesuai tahap kognitif anak relatif akan berpikir konkrit melalui dukungan lingkungan main yang merangsang kreatifitas bereksplorasi dan bereksperimen.

Hal ini sejalan dengan karakteristik yang dimiliki seorang anak terkait kreativitas yang berbeda dengan orang dewasa dimana didominasi akan keunikan gagasan serta imajinasi serta bagaimana anak berfantasi. Sejalan pendapat NACCCE (National Advisory Committte on Creative and Cultural Education), (dalam Debeturu \& Wijayaningsih, 2019) kreativitas merupakan sebuah kegiatan dari imajinasi yang akan menghasilkan sesuatu yang baru dan memiliki nilai yang bermanfaat dalam kehidupan perkembangan seorang anak.

Kreativitas memiliki fungsi mengembangkan seluruh kemampuan potensi anak dalam menggambarkan perasaan serta memperoleh sesuatu yang baru berkaitan dengan proses pembelajarannya. Jika potensi yang dimilikinya dikembangkan dengan baik melalui rancangan pembelajaran bermain kreatif, eksploratif perihal ini didukung dengan hasil penelitian yang dilakukan oleh (Heldanita, 2018) yang menguatkan lingkungan sebagai salah satu media eksploratif yang berperan penting dalam pengembangan kreativitas anak karena anak sebagai manusia unik selalu berinteraksi dengan lingkungan sekitar dalam menggali pengalaman belajarnya. Pemilihan media loose parts juga merupakan salah satu yang diperoleh bersumber lingkungan terdekat anak dimana konsep menurut penelitian yang dilakukan oleh (Nurjanah, 2019)menguatkan barang lepasan yang terbuka sangat mudah dijumpai di lingkungan alam tanpa mengeluarkan biaya tetapi memberikan wadah pada anak untuk menuangkan kreativitas dalam menggunakan benda material bebas sehingga anak memiliki kebebasan bereksperimen dan bereksplorasi.Teori loose parts pertama kali dikembangkan oleh Nicholson pada tahun 1971 berdasarkan keinginan dalam memberikan wadah anak untuk menyalurkan kreativitas menggunakan bahan alam yang dapat dimanipulasi, dipindai, dan diciptakan kembali serta benda atau barangnya yang mudah ditemukan.Menurut Gull dalam (Nurjanah, 2019)

Menurut Casey \& Robertson, (2016) loose parts create richer environments for children to play, giving them the resources they need to do what they need to do. Kebutuhan anak adalah bermain sesuai hak anak yang harus dipenuhi. Bermain adalah penting untuk kesehatan dan kesejahteraan dan mempromosikan pengembangan kreativitas, imajinasi, kepercayaan diri, kemajuan diri, serta kekuatan dan keterampilan fisik social, kognitif dan emosional sehingga seluruh potensi anak berkembang. Itulah alas an utama pemilihan media yang akan digunakan dalam pengembangan kreativitas anak.

Media loose parts merupakan media berbasis bahan alam dimana menurut Yukananda, (dalam Oktari, 2017) disebut bahan alam karena berasal dan disiapkan dari lingkungan sekitar dan 
dimanfaatkan secara sengaja untuk menunjang kegiatan pembelajaran. Bahan alam tersebut seperti batu-batuan, kayu, ranting, biji-bijian, daun kering,pelepah pisang, bambu dimana sudah dipikirkan terkait keamanan untuk anak. Pertimbangan bermain loose parts yang dilakukan oleh penulis adalah tanpa perlu biaya mahal tinggal memanfaatkan dan mengumpulkan bahan-bahan tersebut dari lingkungan alam sekitar dan juga mempertimbangkan membantu mengurangi sampah dengan mengolah bahan yang tidak terpakai menjadi sesuatu yang bermakna.

Konsep loose parts sudah diteliti juga oleh Spencer, dkk, (dalam Mastuinda, et.al. 2020) dimana menegaskan dari hasil penelitian yang dilakukan bermain dengan konsep ini dapat membantu anak ketika berinteraksi hubungan sosialnya, karena mengembangkan keterampilan serta meningkatkan rasa percaya diri beserta kemandirian. Selain itu memanfaatkan loose parts akan menciptakan kreasi yang tiada batasnya bagai diri anak meningkat keinginan kreativitasnya mendalam serta menanamkan kepedulian anak terhadap lingkungan sekitarnya. Anak akan mengoptimalkan seluruh panca inderanya menyerap seluruh kegiatan yang berlangsung dan memperoleh pengalaman berharga dalam informasi pengetahuan.

Hasil pengamatan yang dilakukan diTK Dharma Wanita Wanengpaten Gampengrejo Kediri terdapat permasalahan terkait kreativitas anak usia 5-6 Tahun yaitu belum berkembangnya anak terkait minat dalam eksploratif menyelidiki secara mandiri karena masih menunggu guru dalam memberikan contoh serta belum berkembangnya sikap kreatif mengemukakan idenya sebelum guru memberikan contoh dan akhirnya anak hanya meniru. Meskipun guru tetap mendampingi tetapi dominan teacher centered masih sangat dirasakan dalam proses pembelajaran, sehingga perlu dicarikan solusi pemecahan masalah supaya anak dapat berani aktif, kreatif menuangkan ide gagasannya dengan kegiatan eksploratif sehingga menjadi penemu bukan peniru. Solusi yang ditawarkan adalah penerapan media loose parts sehingga judul yang akan ditulis dalam artikel ini "Penerapan Media Loose Parts Untuk Kreativitas Anak Usia 5-6 Tahun".

\section{Metode}

Metode penelitian yang digunakan dalam metode penelitian adalah deskriptif kualitatif dimana nantinya peneliti akan secara spesifik alamiah menggambarkan terkait data berupa fakta-fakta yang secara nyata berasal dari pelaksanaan pembelajaran yang diterapkan di kelompok B TK Dharma Wanita Wanengpaten terdiri dari 9 anak perempuan dan 15 anak laki-lakidengan jumlah 24 anak, sitematika pembelajaranyang dimulai dari perencanaan, pelaksanaan dan evaluasi pembelajaran yang dilakukan. Sumber data penelitian yang akan digunakan berasal dari kegiatan anak saat bermain loose parts dan hasil karya anak secara langsung didokumentasikan sebagai informan utama 
kemudian dideskripsikan berdasarkan cerita anak. Melalui observasi, wawancara dan dokumentasi menjadi teknik pengumpulan data penelitian ini, dan kemudian diproses dengan cara sitematis agar keabsahan data terlihat dengan triagulasi menghasilkan kesimpulan dengan teknik analisis data menggunakan Miles \& Huberman supaya hasil terkait penerapan media loose partsuntuk Kreativitas Anak Usia 5-6 Tahun di TK Dharma Wanita Wanengpaten Gampengrejo Kediri lebih akurat dan juga sistematis dalam penyajiannya.

\section{Hasil dan Pembahasan}

Untuk pemaparan hasil peneliti akan menguraikan saat proses pelaksaan kegiatan bermain dan strategi pengembangan kreativitas yang dilakukan. Berdasarkan hasil data yang sudah dikumpulkan saat penerapan media loose parts di kelompok B TK Dharma Wanita Wanengpaten ditemukan bahwa, ketika anakanak melakukan aktivitas bermain muncul imajinasi dari mana sumber api dan bagaimana sifat dari api melalui tema yang digunakan adalah tema Air, Udara dan Api. Anak terlihat mampu dalam memanfaatkan alat bahan yang disiapkan oleh guru serta desain perencaraan pembelajaran yang tidak seperti biasanya yang di dominasi atau masih terpaku dengan buku. Kali ini anak diajak belajar dan bermain dengan menyatu bersama alam. Anak sangat antusias mengikuti kegiatan pembelajaran saat itu, kemudian memasuki kegiatan awal dengan kelompok 1 yaitu berteman dengan alam (mengumpulkan bahan alam yang mudah terbakar disekitar lingkungan sekolah, seperti dahan kering, daun, kertas, bungkus jajan dan lain sebagainya), mencoba membuat panas dari batu yang sudah terkumpul serta menghitungnya. Membuat kreasi bebas dari bahan-bahan alam yang sudah terkumpulkan tadi dengan bahan yang disiapkan oleh guru dengan seadanya (lem kayu, batang korek api dan bungkus batang korek api).

Hal ini menunjukan bahwa ketika anak diberi kebebasan dalam melakukan eksplorasi bermain yang hanya disiapkan alat bahan seadanya kemudian diarahkan ternyata hasil karya yang diperolehbisa melebihi target yang sudah guru tentukan sendiri. Bahan cerita anak dari apa yang dibuat menjadi deskripsi hasil karya yang guru sendiri tidak perlu mengarang apa yang sudah dibuat anak. Guru tinggal menuliskan analisis capaian perkembangan anak secara narasi dari bahan yang diceritakan anak.

Guru mendeskripsikan kemampuan anak terkait produk yang original dihasilkan ank dari proses kegiatan imajinasi yang merupakan pola baru dari gabungan informasi yang diperoleh dari pengalaman anak sebelumnya. Hasil karya anak memodivikasi bentuk dalam kegiatan bermain kemudian menyusun menjadi karya adalah bagian dari potensi kreativitas mulai terbentuk dalam diri anak. Selain itu guru melihat bagaimana anak berpeluang berani mengambil resiko akan karyanya yang berbeda 
dengan temannya semakin catatan analisis guru pada capaian perkembangan kreativitas anak semakin tinggi.

Dari hasil diperoleh aktifitas hasil karya anak yang terlihat di bawah ini :

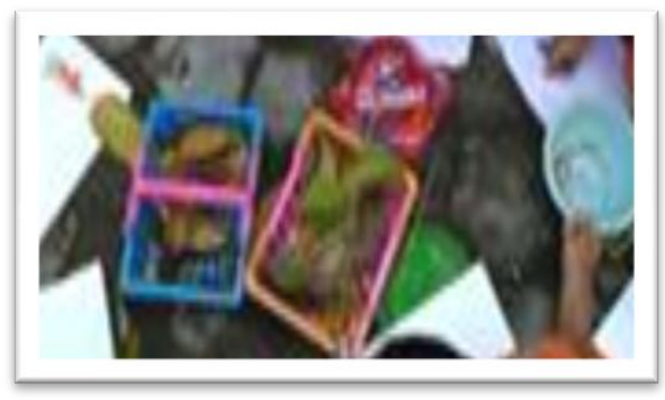

Gambar 3.1

Alat bahan yang disiapkan dalam menerapkan media loose parts

Berdasarkan gambar 3.1 anak mengumpulkan bahan yang diperoleh dari lingkungan sekitar sekolah disini terlihat anak kreatif dan aktif mengambil daun kering terjatuh dibawah pohon , daun masih hijau dipetik langsung dari pohon, daun yang kuning kecoklatan yang jatuh dan masih dipohon, ranting kering, ranting basah diletakan dalam keranjang yang dibawanya berkeliling kemudian dikumpulkan bersama teman-teman untuk selanjutnya mereka menuangkan idenya membuat karya sambil mengajukan pertanyaan pada guru apabila ada yang belum diketahui dan mengajak berbicara teman sebayanya untuk menguatkan idenya tersebut.

Strategi pengembangan kreativitas dengan bermain loose parts menggunakan pendekatan $4 \mathrm{P}$ dalam pengembangan kreativitas anak (Sit. dkk, 2016) dengan paparan sebagai berikut:

a. Pribadi

Adanya keunikan individu anak akan ditekankan terkait interaksi dengan lingkungan dalam menuliskan penilaian sebagai bentuk interaksi bermain loose parts secara mandiri

b. Pendorong

Guru hanya akan melakukan kegiatan memeberikan dorongan atau motivasi tanpa memebrikan contoh agar anak terdorong sendiri berkreasi tanpa ada paksaan dan dituntut sesuai contoh guru.

c. Proses

Tidak kalah penting guru harus menghargai setiap proses yang dilalui anak dalam upaya pengembangan kreativitas dalam dirinya dengan tidak memberikan komentar negatif tetapi dilihat apabila anak berani mencoba berilah penghargaan berupa pujian positif untuk meningkatkan kepribadian anak lebih berani lagi mencoba.

d. Produk

Bagaimana produk yang akan dihasilkan anak dilihat tingkat kreatifi yang bermakna berdasarkan keunikan kondisi masingmasing individu serta lingkungan berupa proses terlihat saat 
anak memiliki kesibukan beraktivitas kegiatan dalam memunculkan kreasinya.

Kemudian aktivitas anak terlihat seperti dokumentasi dibawah ini:

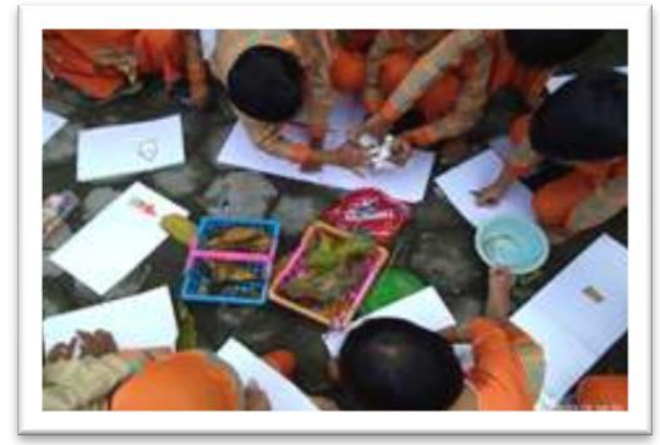

Gambar 3.2

Anak membuat kreasi dari bahan-bahan alam sekitar

Gambar 3.2 menggambarkan betapa senangnya anak melakukan bermain dari material loose parts alam yang diperolehnya. Bermain memang dunia anak dan hak anak sesuai pendapat Catron \& Allen, (dalam Lestariningrum, 2018) menguatkan ketika anak bermain akan menjadi rangkaian proses yang menjadi jati diri anak tidak terpisahkan dan anak akan berkembang terhadap aspek kognitifnya termasuk di dalamnya kreativitasnya. Guru kemudian berkelilig untuk bertanya pada anak proses ide yang dibuat diwujudkan karya atau sekedar mengajak anak bercakap tentang ide yang dimilikinya, menanyakan pada anak tentang yang akan dibuat, menanyakan pada anak jika bekerja bersama teman pentingnya karya itu dikerjakan bersama. Intinya pertanyaan spontan yang dilontarkan guru akan merangsang anak kreatif menjawab dengan beragam jawaban tanpa adanya guru mengarahkan salah satu jawaban tertentu.

Guru harus siap untuk memberikan respon terhadap pertanyaan serta tidak kalah pentingnya memebrikan kesempatan kepada anak untuk melakukan kegiatan berpikir sebelum bertanya maupun menjawab pertanyaan. Mengapa ini penting dilakukan dan dipahami guru tidak semua anak bisa lanagsung secara cepat menjawab tahapan berbeda terhadap kecepatan berpikirnya. Guru menstimulasi cara beragam agar anak tumbuh keberaniannya buat suasana nyaman tidak ada ketegangan saat kegiatan berlangsung. Tentu saja saat mengajukan pertanyaan atau menjawab pertanyaan pembiasaan menggunakan kata-kata yang sopan, tidak berebut juga dilakukan oleh guru.

Panduan-panduan pertanyaan guru bisa menyiapkan sesuai dengan indikator yang ditetapkan. Hal ini perlu dipikirkan oleh guru karena anak masih pada tahap berpikir konkrit sehingga harus bisa dipahami anak dengan mudah dalam bertanya. Pertanyaan ini juga untuk menstimulasi terciptanya generasi yang 
perkembangannya tercapai optimal dengan kemampuan yang dibutuhkan dimasa sekarang yaitu anak yang mampu memiliki pola pikir memfasilitasi rasa ingin tahu anak dan tidak membatasi jawaban anak pada satu kunci jawaban yang pasti.

Setelah selesai kegiatan capaian hasil perkembangan anak selama proses bermain dengan media loose parts dapat dilihat di bawah ini:

\section{Tabel 3.1. Pedoman Penilaian Wawancara Kreativitas Anak Dengan Media Loose Parts}

\begin{tabular}{|c|c|}
\hline Indikator & Pertanyaan \\
\hline $\begin{array}{l}\text { Menghargai hasil karya orang lain } \\
\text { (Nam 1.2) }\end{array}$ & $\begin{array}{lrr}\text { Mengapa saat } & \text { temanmu } \\
\text { bercerita kita } & \text { harus } \\
\text { mendengarkan? } & \end{array}$ \\
\hline $\begin{array}{l}\text { Menjawab pertanyaan lebih } \\
\text { komplek (nama bahan dan ide apa } \\
\text { yang dibuat dari bahan tersebut) } \\
\text { (Bhs. } 3.11-4.11 \text { ) }\end{array}$ & $\begin{array}{l}\text { Apa nama bahan yang kamu } \\
\text { gunakan dan apa yang akan } \\
\text { kamu buat dari bahan } \\
\text { tersebut? }\end{array}$ \\
\hline 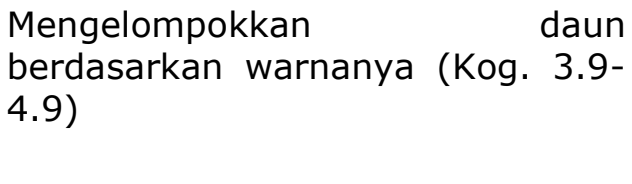 & $\begin{array}{l}\text { Berapa jumlah daun yang } \\
\text { sudah dikelompokan } \\
\text { berdasarkan } \quad \text { warnanya } \\
\text { masing-masing? }\end{array}$ \\
\hline $\begin{array}{l}\text { Membuang sampah pada } \\
\text { tempatnya setelah bermain loose } \\
\text { parts (FM.2.1) }\end{array}$ & $\begin{array}{lr}\text { Mengapa sampah } & \text { harus } \\
\text { dibersihkan } & \text { setelah } \\
\text { bermain? } & \end{array}$ \\
\hline $\begin{array}{ll}\text { Menyelesaikan } & \text { tugas } \\
\text { mandiri (SE.2.7) } & \end{array}$ & $\begin{array}{l}\text { Mengapa tugasnya harus } \\
\text { selesai dalam mengerjakan? }\end{array}$ \\
\hline $\begin{array}{l}\text { Tertarik aktivitas seni/berkreasi } \\
\text { bebas dari bahan alam (Seni, } \\
3.15-4.15 \text { ) }\end{array}$ & $\begin{array}{l}\text { Bagaimana proses membuat } \\
\text { kreasimu dari bahan yang } \\
\text { kamu pilih? }\end{array}$ \\
\hline
\end{tabular}

Berdasarkan indikator dan pertanyaan di tabel 3.1 diperoleh data hasil capaian perkembangan kognitif anak yang mengarah pada capaian kreativitas anak digambarkan dalam diagram batang seperti berikut ini:

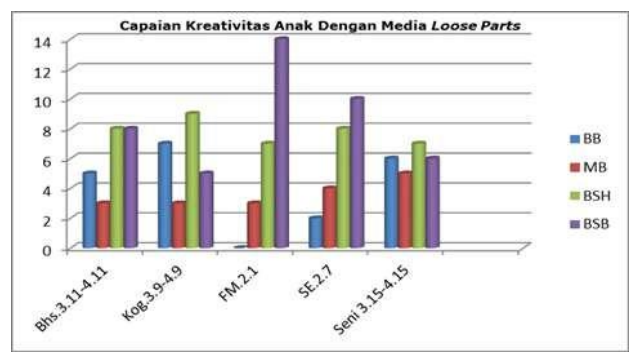

Diagram 3.1: Capaian Kreativitas anak dengan media loose parts 
Hasil paparan yang dijabarkan diatas menegaskan bahwa kegiatan bermain loose parts merupakan solusi yang tepat efektif meningkatkan kreatifitas anak ketika anak melakukan eksplorasi bereksperimen secara tidak langsung sudah berinteraksi dengan dirinya sesuai kemauan anak dan interaksi dengan lingkungannya menemukan kepuasan diri seperti pendapat Montolalu, (2008) kreativitas dikembangkan dengan memberikan kesempatan anak secara bebas dalam mengekspresikan diri, menemukan sendiri alternative memecahkan masalah, adanya keterbukaan dan kepuasan diri saat beraktifitas main. Menurut Munandar, (dalam Fatmawijayati, 2018) kreativitas yang diperoleh anak dengan memanfaatkan bahan lepasan di sekitar merupakan kombinasi pengetahuan anak yang sudah diperoleh diciptakan ulang digabung dengan gagasannya sebagai bentuk penggabungan pengalaman serta pengetahuan yang dipunyai anak. Barangbarang yang ditemukan secara mudah itulah menurut Siantajani, dalam (Prameswari, \& Lestaringrum 2020) akan sangat membantu pencapaian saat anak bermain. Melalui bahan lepasan anak dapat menyampaikan idenya sendiri, itulah media loose parts yang sesungguhnya.

Pengembangan kreativitas yang dilakukan dengan bermain loose parts juga dilakukan oleh Muqowin \& Imamah, (2020) dimana menegaskan bahwa kreativitas terstimulasi dengan tepat dengan bermain ini karena guru menjadi fasilitator dalam menstimulasi dan mendorong perkembangan kreativitas anak. Akan melahirkan sebuah gagasan, proses serta adanya produk yang bisa jadi modifikasi atau baru karena memanfaatkan imajinasi yang fleksibel. Bermain itu memiliki kebebasan, keluwesan serta memberikan pengalaman baru, sebagai hiburan yang kreatif dimana anak akan mengambil satu keputsa dari beragam permasalahan yang dihadapinya saat diberikan bermain dengan media beragam dan tidak ada contohnya dari guru. Guru hanya mengajak anak menggali pengalaman yang dimilikinya sebelumnya.

Kegiatan yang dilakukan anak saat bermain, dengan mengajukan pertanyaan juga mencirikan ciri anak kreatif menurut (Mulyati \& Sukmawijaya, 2013) ketika anak mandiri dan berkonsentrasi dalam mengerjakan tugas dalam waktu yang relative lama, anak memanipulasi bahan dengan berekplorasi, menjawab pertanyaan dengan beragam kreatifitas jawaban sendiri merupakan ciri yang ada di bermain tersebut. Anak dapat menciptakan gagasan ide kreatif dari pengalaman saat berinteraksi dengan lingkungan sekitarnya dilakukan sederhana ketika menyelesaikan sebuah bermain baik sendiri maupun berkelompok akan meningkatkan kemampuan kreativitas sejak dini. Loose parts play emerges as recent issue on creative learning(Shabrina \& Lestariningrum, 2020) dengan ini menegaskan pembelajaran kreatif adalah pembelajaran dengan media loose parts dimana akan dilakukan dengan menyenangkan, 
tanpa aturan yang mengikat serta memberikan kebebasan anak memilih yang sesuai keinginan dalam fleksibelnya bahan yang digunakan saat eksplorasi.

Eksplorasi merupakan aktivitas yang memuat pengamatan mendalam, menurut Pamilu, dalam (Heldanita, 2018) sebuah gagasan ide bersifat kreatif akan muncul secara otomatis dari eksplorasi tentang sesuatu hal dimana kesempatan yang diberikan pada anak mengoptimalkan panca inderanya melalui penglihatan, memahami, merasakan serta akhirnya mereka dapat menyampaikan hasil dari proses menjadi kesimpulan sederhana sesuai tahapan yang dimilikinya. Hal ini ditegaskan Krogh \& Slentz, dalam (Wahyuningsih et al., 2019) kegiatan yang memunculkan kreativitas adalah rancangan kegiatan yang membuat rasa ingin tahu anak berkembang karena penasaran dilakukan dengan semangat dan rasa ingin terus mencoba karena haus akan adanya belajar tentang sesuatu yang baru. Diperkuat Nurjanah, (2020) loose parts tidak hanya sekedar mendukung terkait perkembangan kreativitas anak tetapi juga akan lebih mendekatkan anak dengan lingkungannya.

Selain itu pendapat dari Fauziah, (2018) menegaskan akan rancangan kegiatan pembelajaran dengan media berbasis bahan alam akan lebih membuat kegiatan bermain dalam belajar anak menarik serta bervariasi dimana ini akan meningkatkan kreativitas anak karena lebih banyak mengeksplorasi beragam alat main dari lingkungan sekitar berbasis alam. Anak akan terstimulasi dalam berpikir kreatif dan juga menggunakan fantasi dan imajinasinya dimana hal tersebut akan melekat dalam memori anak karena dilakukan dengan bermai yang sukarela dan menyenangkan.

Dari kegiatan berupa dokumentasi hasil karya anak bermain loose parts diharapkan dapat memiliki manfaat bagi anak khususnya dalam kehidupan selanjutnya. Hal ini sejalan dengan pendapat Munandar, (dalam Susanto, 2014) dimana manfaat tercapainya kreativitas pada diri anak akan memungkinkan seorang individu meningkat dalam kualitas hidupnya. Perkembangan pengetahuan dan teknologi menuntut terciptanya sumbangan ide kreatif, ide segar dan menemukan hal-hal baru yang bermanfaat untuk masyarakat tentunya tidak instan tetapi harus distimulasi sejak dini, agar individu mulai usia dini akan memiliki konsep menciptakan tidak tergantung pada hasil ciptaan orang lain. Selaian itu bermain loose partsmembuat anak terbiasa berkreasi. Sekaligus memanfaatkan bahan murah, mudah didapat, dan tentu saja ramah lingkungan yang menujang pembelajaran anak.

Penelitian yang dilakukan oleh Lestariningrum \& Wijaya, (2020) juga mengungkapkan sebuah hasil kegiatan bermain loose parts memiliki keefektifan dalam pengembangan kognitif pada pemecahan masalah dimana tentunya kajaian seorang anak menggunakan proses berpikir dalam memecahkan maslah juga salah satu dari pengembangan kreativitas karena tidak ada satu 
perintah pasti dalam kegiatan bermain tetapi anak akan memainkan ragam ide imajinasinya menggunakan benda-benda yang ada di sekitarnya. Saat temanyya bermain anak juga akan menjadi pengamat yang ulung bisa jadi ia menemukan ide lain setelah melihat karya temannya karena proses berpikir anak yang memiliki keunikan tersendiri perlu ada motivasi terlebih dahuli dari teman sebayanya maupun orang tua guru didekatnya.

Hasil penelitian yang dipaparkan oleh peneliti memunculkan sebuah hasil orisinil anak berkarya menggunakan bahan loose parts yang difasilitasi guru menyiapka dan menata alat main. Menurut Runco dan Jaeger, (dalam Kusumawardani. et.al, 2018) orisinalitas merupakan sebuah nilai utama dan pokok dalam konsep kreativitas dimana seimbang dengan nilai kepantasan serta manfaat bagi kebutuhan perkembangan anak. Proses penyiapan bermain loose parts sebagai bagian dari proses pembelajaran dimana pembelajaran menurut Sadiman, (dalam Kusumawardani. et.al, 2018) adalah sebuah usaha sebagai bentuk manipulasi dari beragam sumber belajar supaya proses belajar dalam peserta didik berjalan dengan efektif dengan memberikan kesempatan seluas-luasnya pada anak melakukan aktivitas kegiatan secara mandiri.

\section{Kesimpulan}

Paparan yang disajikan secara paparan naratif dilengkapi pembahasan dengan data yang diperoleh dapat disimpulkan bahwa melalui media loose parts dapatmeningkatkan kreativitas anak, hal ini menyesuaikan dengan rumusan masalah dan tujuan penelitian. Saat anak melakukan eksplorasi langsung di lingkungan memperkaya ide kreatif, rasa ingin tahu mencoba menemukan dengan optimaslisasi panca indera anak. Melalui strategi tahapan yaitu dimulai dari pribadi, pendorong, proses dan produk yang diamati guru diharapkan dapat mengembangkan kreativitas anak lebih optimal.

Dari hasil dan pembahasan diatas, disarankan kepada guru PAUD dalam meningkatkan kreativitas anak dapatmengunakan media loose parts dengan bahan dari lingkungan sekitar anak. Bahan lepasan yang disekitar lingkungan anak memiliki keanekaragaman yang dapat memperkaya kegiatan bermain anak dalam menuangkan ide kreatifnya. Selain itu guru dapat mencoba strategi lain ataupun sama dengan peneliti tetapi lebih dikembangkan sesuai dengan kondisi masing-masing peserta didik dan kemampuan yang dimiliki guru dalam penerapan saintifik di lembaga PAUD tempatnya mengajar.

\section{Ucapan Terima Kasih}

Saya sampaikan ucapan terima kasih kepada kepala sekolah dan guru-guru TK Dharma Wanita Wanengpaten Kecamatan Gampengrejo Kabupaten Kediri, Jawa Timur yang sudah membantu pelaksanaan penelitian. Juga saya ucapkan terima kasih kepada dosen PG-PAUD, FKIP, Universitas Nusantara PGRI 
Kediri yang sudah mengarahkan dan membimbing hasil penelitian menjadi karya ilmiah yang dapat dipublikasikan di jurnal ilmiah, atas bimbingan beliau saya memasukan nama Dr. Anik Lestariningrum, M.Pd sebagai author ke-2 karena ikut memberikan kontribusi di artikel ilmiah ini dan terlibat dalam penulisan sampai karya ilmiah ini selesai.

\section{Daftar Pustaka}

Casey, Theresea \& Juliet Robertson. (2016). Loose Parts Play. Inspiring Scotland.

Debeturu. B. \& Wijayaningsih. L. (2019). Meningkatkan Kreativitas Anak Usia 5-6 Tahun Melalui Media Magic Puffer Ball. Jurnal Obsesi: Jurnal Pendidikan Anak Usia Dini, Vol.3 Issue 1 (2019) Pages 233-240. DOI: https://doi.org/10.31004/obsesi.v3i1.180

Fatmawijayati., J. 2018. Telaah Kreativitas. See discussions, stats, and author profiles for this publication at: https://www.researchgate.net/publication/328217424.

Fauziah, N. (2018). Penggunaan Media Bahan Alam Untuk Meningkatkan Kreativitas Anak. JIV, 8(1), 23-30. https://doi.org/10.21009/jiv.0801.4

Heldanita. (2018). Pengembangan Kreativitas Melalui Eksplorasi. Golden Age Jurnal IImiah Tumbuh Kembang Anak Usia Dini.

Istianti, T. (2018). Pengembangan Kreativitas Anak Melalui Pemanfaatan Lingkungan Sekitar Sebagai Media Belajar Bagi Anak Usia Dini. Cakrawala Dini: Jurnal Pendidikan Anak Usia Dini. https://doi.org/10.17509/cd.v4i2.10393

Kusumawardani. R. et.al. (2018). Profil Kreativitas Anak Usia 5-6 Tahun. Jurnal Ilmiah VISI PGTK PAUD dan DIKMAS-Vol.13, No.1, Juni 2018.

Lestariningrum., Anik. (2018). The Effects of Tradisional Game "Congklak " and Self-Confidence Toward Logical Mathematical Intelligence of 5-6 Years Children. Jurnal Indria Vol.III (1) March 2018, pp;13-22, ISSN 2524-004X 10.24269/jin.v3n1.2018.pp13-22

Lestariningrum. A, \& Wijaya. I.P. (2020). Penerapan Bermain Loose Parts Untuk Kemampuan Memecahkan Masalah Sederhana Anak Usia 4-5 Tahun. Jurnal Pedagogika. Vol.11, No.2, pp; 104-115

Mulyati, S., \& Sukmawijaya, A. A. (2013). Meningkatkan Kreativitas pada Anak. Jurnal Inovasi Dan Kewirausahaan.

Mulyana., Aina. (2017). Pembelajaran Abad 21 Dan Kurikulum 2013.

https://ainamulyana.blogspot.com/2017/03/pembelajaranabad-21-dan-kuikulum-2013.html 
Montolalu. W (2008) Bermain Dalam Kelompok, Bermain Bola, Bermain dengan Angka. Jakarta: Grasindo

Mastuinda, et.al. (2020). Persepsi guru Tentang Penggunaan Loose Parts Dalam Pembelajaran Di PAUD Se-Kecamatan Tampan Kota Pekanbaru. Jurnal JRPP. Vol. 3, No.1, Juni 2020.

Muqowin, \& Imamah. Z. (2020). Pengembangan Kreativitas dan Berpikir Kritis Pada Anak Usia Dini melalui Metode Pembelajaran Berbasis STEAM and Loose Parts. YINYANG. Jurnal Studi Islam, Gender, dan anak. Vol.15, No.2 Juli 2020.https://doi.org/10.24090/yinyang.v15i2.3917

Nurjanah, N. E. (2019). Pembelajaran STEM Berbasis Loose Parts untuk Meningkatkan Kreativitas Anak Usia Dini. AUDI: Jurnal IImiah Kajian IImu Anak Dan Media Informasi PUD.

Oktari. V. M. (2017). Penggunaan Media bahan Alam dalam Pembelajaran Di Taman Kanak-kanak Kartika I-63 Padang. PAUD Lectura: Jurnal Pendidikan Anak Usia Dini, Vol.1, No.1, Oktober 2017.

Prameswari, T. W \& Lestariningrum, A. (2020). STEAM Based Learning Strategies by Playing Loose Parts for the Achievement of 4C Skills in Children 4-5 Years. Jurnal Efektor, 7 (1), pp: 24-34.

Shabrina, E., \& Lestariningrum, A. (2020). The role of loose parts play in logical thinking skill in KB Lab school. Journal of Early Childhood Care and Education. https://doi.org/10.26555/jecce.v3i1.1679

Sit. Masganti, dkk. (2016). Pengembangan Kreativitas Anak Usia Dini (Teori dan Praktik). Cetakan pertama. Medan: PERDANA PUBLISHING. ISBN: 978-602-6462-11-4

Susanto, A. (2014). Perkembangan Anak Usia Dini. Pengantar dalamBerbagai Aspeknya. Jakarta: Prenada Media Group.

Wahyuningsih, S., Pudyaningtyas, A. R., Hafidah, R., Syamsuddin, M. M., Nurjanah, N. E., \& Rasmani, U. E. E. (2019). Efek Metode STEAM pada Kreatifitas Anak Usia 5-6 Tahun. Jurnal Obsesi: Jurnal Pendidikan Anak Usia Dini. https://doi.org/10.31004/obsesi.v4i1.305 